\title{
Regulation of Wnt signaling activity for growth suppression induced by quercetin in 4T1 murine mammary cancer cells
}

\author{
HAESUNG KIM $^{3}$, EUN-MIN SEO ${ }^{1}$, ASHISH R. SHARMA ${ }^{1,2}$, BILGUUN GANBOLD ${ }^{1,2}$, JONGBONG PARK ${ }^{1,2}$, \\ GARIMA SHARMA ${ }^{1,2,5}$, YOUNG-HEE KANG ${ }^{4}$, DONG-KEUN SONG ${ }^{2}$, SANG-SOO LEE $^{1,2}$ and JU-SUK NAM ${ }^{1,2}$ \\ ${ }^{1}$ Institute for Skeletal Aging and Orthopaedic Surgery, Chuncheon Sacred Heart Hospital; \\ ${ }^{2}$ Infectious Diseases Medical Research Center; ${ }^{3}$ Department of Surgery, Chuncheon Sacred Heart Hospital, \\ College of Medicine; ${ }^{4}$ Department of Food and Nutrition, Hallym University, Chuncheon, Republic of Korea; \\ ${ }^{5}$ Amity Institute of Nanotechnology, Amity University Uttar Pradesh, Noida, India
}

Received May 23, 2013; Accepted July 1, 2013

DOI: $10.3892 / \mathrm{ijo} .2013 .2036$

\begin{abstract}
Quercetin is a promising chemopreventive agent against cancer that inhibits tumor progression by inducing cell cycle arrest and promoting apoptotic cell death. Recently, the Wnt/ $\beta$-catenin signaling pathway has been implicated in mammary tumorigenesis, where its abnormal activation is associated with the development of breast cancer. Thus, the objective of this study was to examine the biological activities of quercetin against mammary cancer cells, and to determine whether quercetin could regulate the Wnt/ $\beta$-catenin signaling pathway. Quercetin showed dose-dependent inhibition of cell growth and induced apoptosis in 4T1 cells. Treatment of $20 \mu \mathrm{M}$ quercetin suppressed $\sim 50 \%$ of basal TopFlash luciferase activity. Moreover, the inhibitory effect of quercetin on the Wnt $/ \beta$-catenin signaling pathway was confirmed by the reduced stabilization of the $\beta$-catenin protein. Among various antagonists screened for the Wnt/ $\beta$-catenin signaling pathway, the expression of DKK1, 2 and 3 was induced after treatment with $20 \mu \mathrm{M}$ of quercetin. Stimulation with recombinant DKK1 protein, showed suppressive cell growth of mammary cancer cells instead of quercetin. When 4T1 cells were treated with recombinant Wnt3a or $\mathrm{LiCl}$ along with quercetin, both stimulators for the $\mathrm{Wnt} / \beta$-catenin signaling pathway were able to restore the suppressed cell viability by quercetin. Thus, our data suggest that quercetin exerts its anticancer activity through the downregulation of $\mathrm{Wnt} / \beta$-catenin signaling activity. These
\end{abstract}

Correspondence to: Professor Sang-Soo Lee, Institute for Skeletal Aging and Orthopaedic Surgery, Hallym University-Chuncheon Sacred Heart Hospital, 153 Gyodong, Chuncheon, Gangwon-do 200-702, Republic of Korea

E-mail: totalhip@hallym.ac.kr

Dr Ju-Suk Nam, Infectious Diseases Medical Research Center, College of Medicine, Hallym University, 39 Hallymdaehak-gil, Chuncheon, Gangwon-do 200-702, Republic of Korea

E-mail: jsnam88@hallym.ac.kr

Key words: quercetin, anticancer, Dickkopf 1, Wnt signaling results indicate for the first time that quercetin decreases cell viability and induces apoptosis in murine mammary cancer cells, which is possibly mediated by DKK-dependent inhibition of the Wnt/ $\beta$-catenin signaling pathway. In conclusion, our findings suggest that quercetin has great potential value as chemotherapeutic agent for cancer treatment, especially in breast cancer controlled by Wnt/ $\beta$-catenin signaling activity.

\section{Introduction}

Breast cancer is the most common malignancy among females, accounting for nearly 1 in 3 cancers diagnosed in women worldwide, and it is the second leading cause of cancer death after lung cancer (1). The major treatment procedures for breast cancer patients are surgery, radiotherapy and chemotherapy; however, the cure rates are not satisfactory. New agents acting on novel targets in breast cancer are currently under investigation.

The role of dietary flavonoids in cancer prevention is widely discussed. Convincing data from laboratory studies, epidemiological investigations, and human clinical trials indicate that flavonoids have imperative effects on cancer chemoprevention and chemotherapy (2). Quercetin (3,3',4',5,7-pentahydroxyavone), a member of the flavonoids family, is one of the most prominent dietary antioxidants present in human diet $(3,4)$ and exerts diverse biological activities in a variety of cancer cell model, including ovarian, endometrial, lymphoma, prostate, liver and gastric cancer (5-7). Although precise molecular mechanisms underlying quercetin-mediated cellular responses on breast cancer remain poorly defined, prior research has shown that it can modulate diverse proteins involved in signal transduction pathways associated with cell survival, apoptosis and proliferation (8-10).

Current studies have shown the importance of several signaling pathways in breast carcinogenesis and progression $(11,12)$ including the $\mathrm{Wnt} / \beta$-catenin pathway $(13-15)$. The $\mathrm{Wnt} / \beta$-catenin pathway plays a vital role in mammary tumorigenesis since overexpression of Wnt 1 gene in the mammary epithelium is sufficient for mammary gland hyperplasia and adenocarcinomas (16). The canonical Wnt ligands, exemplified by Wnt1 or Wnt3a, bind to frizzled receptor $(\mathrm{Fz})$ and the 
Table I. Primers for real-time RT-PCR.

\begin{tabular}{lllrr}
\hline Gene & \multicolumn{1}{c}{ Forward primer $\left(5^{\prime} \rightarrow 3^{\prime}\right)$} & \multicolumn{1}{c}{ Reverse primer $\left(3^{\prime} \rightarrow 5^{\prime}\right)$} & Size $(\mathrm{bp})$ & Accession no. \\
\hline DKK1 & TCAGGTCCATTCTGGCCAACTCTT & TGGGCATTCCCTCCCTTCCAATAA & 132 & NM_010051.3 \\
DKK2 & ATGGCAGAATCTAGGAAGGCCACA & CGAACCCTTCTTGCGTTGTTTGGT & 184 & NM_020265.4 \\
DKK3 & AGCTGATGGAAGACACTCAGCACA & TCCTGGTGCACATGGACTGTGTTA & 175 & NM_015814.2 \\
DKK4 & ATGGTACTGGTGACCTTGCTTGGA & TCCGCGGAGCTCTTGATGTTGTTA & 92 & NM_145592.2 \\
GAPDH & TCAACAGCAACTCCCACTCTTCCA & ACCCTGTTGCTGTAGCCGTATTCA & 115 & NM_008084.2 \\
\hline
\end{tabular}

low-density lipoprotein receptor-related protein-5/6 (LRP5/6), and prevent phosphorylation and degradation of $\beta$-catenin by the GSK3//APC/axin destruction complex. Subsequent accumulation of cytosolic and nuclear $\beta$-catenin bound to $\mathrm{T}$ cell factor (TCF) transcription factors results into activation of downstream signals which are important for proliferation and matrix remodeling (17). The elevated levels of nuclear and/or cytoplasmic $\beta$-catenin in breast carcinomas correlated with the expression of its target gene cyclin D1 and poor patient prognosis (18). In a microarray based study, Huang et al (19) showed that inhibition of $\mathrm{Wnt} / \beta$-catenin pathway leads to apoptosis in HeLa cells by upregulating the expression of several pro-apoptotic genes, involved in apoptotic cell death pathways, such as PTEN-PI3K-AKT pathway, NFאB pathway and p53 pathway. Furthermore, studies in mice strongly imply that deregulated $\beta$-catenin signaling increases risk of breast cancer by inducing stem cell and early progenitor cell accumulation $(20,21)$. Several studies have accounted for increased cytoplasmic and nuclear $\beta$-catenin in primary breast cancers, especially basal-like breast cancers, and correlated with poor prognosis and survival $(22,23)$. Thus, it needs to be investigated whether the activation of $\mathrm{Wnt} / \beta$-catenin signaling can be a potential target for the chemoprevention and treatment of breast cancer.

To identify molecular mechanism for quercetin-induced apoptosis, we used the murine mammary carcinoma cell line, 4T1, which is highly tumorigenic and invasive (24). Contrary to most tumor models, 4T1 cells injected into the mammary fat pads of syngeneic BALB/c mice grow spontaneously into multiple distant organs such as lymph nodes, liver, lung, brain and bone (25). Therefore, 4T1 is widely used as one of the most aggressive type of breast cancer cell for the study of breast cancer. Although quercetin has been reported to stimulate cell cycle arrest and apoptosis in breast cancer cells (26) the exact molecular mechanism of action still remains unclear. In this study, we show that quercetin induces apoptosis of mammary cancer cells through DKK-dependent inhibition of the Wnt/ $\beta$-catenin signaling pathway.

\section{Materials and methods}

Cell culture and reagents. Murine mammary cancer cell line 4T1 (ATCC, CRL-2539) was cultured in RPMI-1640 (Invitrogen, Carlsbad, CA) supplemented with $10 \%$ fetal bovine serum (FBS), $100 \mathrm{U} / \mathrm{ml}$ penicillin and $100 \mathrm{U} / \mathrm{ml}$ streptomycin (Lonza, Basel, Switzerland) at $37^{\circ} \mathrm{C}$ and $5 \% \mathrm{CO}_{2}$. Quercetin was purchased from Sigma (St. Louis, MO, USA). A stock solution $(25 \mathrm{mM})$ of quercetin was prepared in dimethyl-sulfoxide
(DMSO). Recombinant proteins, Wnt3a and DKK1, were purchased from R\&D Systems (Minneapolis, MN).

MTT assay. MTT assay was carried out to evaluate the viabilities of 4T1 cells, and performed using 3-(4,5-dimethylthiazol-2-yl)-2,5-diphenyl-tetrazolium bromide (MTT; Sigma). 4T1 cells $\left(1.5 \times 10^{4}\right.$ cells/well $)$ were plated in 96 -well plates and allowed to attach overnight. Cells were then treated with quercetin at various concentrations $(5,10,20$ and $40 \mu \mathrm{M})$ or the vehicle $\left(0.16 \%\right.$ of DMSO) and incubated at $37^{\circ} \mathrm{C}$ with $5 \% \mathrm{CO}_{2}$ for $48 \mathrm{~h}$. Fresh MTT ( $\left.5 \mathrm{mg} / \mathrm{ml}\right)$ was added to growing cells in 96 -well plate and incubated at $37^{\circ} \mathrm{C}$ for $2 \mathrm{~h}$. Following the removal of supernatant, the insoluble formazan crystals were dissolved in $200 \mu \mathrm{l}$ of DMSO and optical density was measured at wavelength of $570 \mathrm{~nm}$.

Assessment of cell apoptosis. 4T1 cells were treated with quercetin $(20 \mu \mathrm{M})$ for $48 \mathrm{~h}$, and then apoptotic cells were quantified by using an Annexin V-FITC/PI double staining assay kit (BD Pharmingen, San Diego, CA). Both, early and late apoptotic changes in 4T1 cells were analyzed. Briefly, cells $\left(1 \times 10^{6}\right)$ were collected and washed twice with phosphate-buffered saline (PBS) and suspended in $400 \mu \mathrm{l}$ of binding buffer (added with $5 \mu \mathrm{l}$ of Annexin V-FITC and $5 \mu \mathrm{l}$ of PI). The combination of Annexin V-FITC and PI staining permitted the simultaneous quantification of vital, apoptotic and necrotic cells. Thereafter, the samples were incubated in the dark for $15 \mathrm{~min}$ at room temperature, and then analyzed on the flow cytometer. The number of Annexin V-FITC-positive and PI-positive cells in each field was determined by counting the cells directly. Experiments were performed in triplicate for accuracy.

RNA isolation andreal-time RT-PCR. Total RNA was extracted using TRIzol reagent (Invitrogen). RNA purity was verified by measuring 260/280 absorbance ratio. The first strand of cDNA was synthesized with $2 \mathrm{mg}$ of total RNA using SuperScript II (Invitrogen), and one-tenth of the cDNA was used for each PCR mixture containing Express SYBR-Green qPCR Supermix (BioPrince, Seoul, Korea). Real-time PCR was performed using a Rotor-Gene Q (Qiagen, Hilden, Germany). The reaction was subjected to 40 -cycle amplification at $95^{\circ} \mathrm{C}$ for $20 \mathrm{sec}$, at $60^{\circ} \mathrm{C}$ for $20 \mathrm{sec}$ and at $72^{\circ} \mathrm{C}$ for $25 \mathrm{sec}$. Relative mRNA expression of selected genes was normalized to GAPDH and quantified using the DDCT method. The sequences of the PCR primers are listed in Table I.

Luciferase reporter assay. 4T1 cells were plated at a density of $2 \times 10^{4}$ cells/well in 48 -well plates, and transfected using 
A

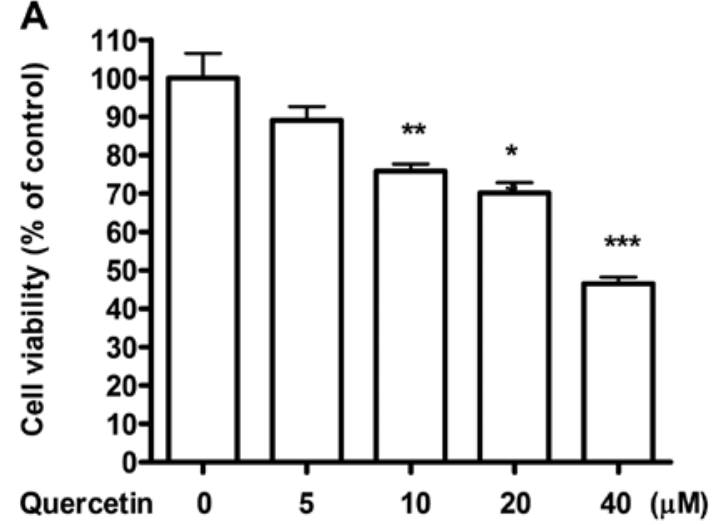

B

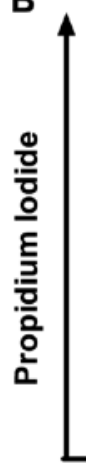

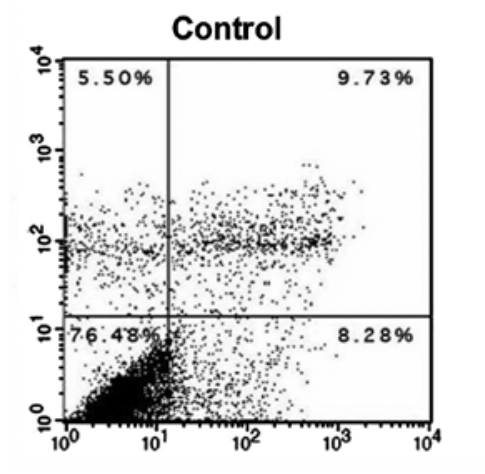

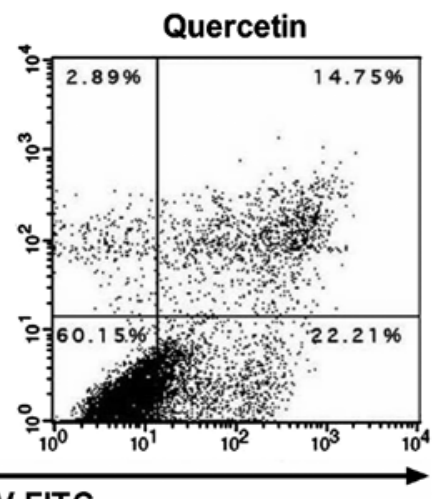

Figure 1. Quercetin treatment reduces cell viability and induces apoptosis in mouse breast cancer cells. (A) 4T1 cells were treated with vehicle (DMSO) and various doses $(5,10,20$ and $40 \mu \mathrm{M})$ of quercetin for $48 \mathrm{~h}$ and cell viability was analyzed by MTT assay. (B) $4 \mathrm{~T} 1 \mathrm{Cells}$ were treated with quercetin (20 $\mu \mathrm{M})$ for $48 \mathrm{~h}$. After incubation, cells were stained with Annexin V and PI and analyzed by flow cytometry. The upper left quadrant contains the necrotic (FITC/PI ${ }^{+}$ population. The upper right quadrant contains the late apoptotic/necrotic ( $\left.\mathrm{FITC}^{+} / \mathrm{PI}^{+}\right)$population. The lower left quadrant contains the vital (FITC-/PI-) population. The lower right quadrant contains the early apoptotic $\left(\mathrm{FITC}^{+} / \mathrm{PI}^{-}\right)$population. The result is from one experiment representative of three similar experiments. Data are shown as the mean $\pm \mathrm{SD}$. Similar results were obtained in three independent experiments. ${ }^{* *} \mathrm{P}<0.01$ and ${ }^{* * *} \mathrm{P}<0.001$.

Genefectine transfection reagent (Genetrone Biotech Co., Korea) according to the manufacturer's protocol. The TopFlash (Addgene, Cambridge, MA) luciferase reporter (100 ng) and Renilla luciferase thymidine kinase construct (Invitrogen) (50 ng) were used to determine luciferase activity. Luciferase activity was measured by a luminometer (Glomax, Promega, Sunnyvale, CA), using a Dual-Luciferase assay kit (Promega), according to the manufacturer's recommendations. Total value of reporter activity in each sample was normalized to Renilla luciferase activity.

Protein isolation and western blot analysis. Cells were lysed in RIPA buffer (20 mM Tris- $\mathrm{HCl}$, pH 7.5, $200 \mathrm{mM} \mathrm{NaCl}$, $1 \%$ Triton $\mathrm{X}-100,1 \mathrm{mM}$ dithiothreitol) containing protease inhibitor cocktail (Roche). The concentration of protein was measured with a Protein assay kit (Bio-Rad) following the manufacturer's protocol. Total protein was subjected to SDS-polyacrylamide gel electrophoresis and transferred to a PVDF membrane. The blot was probed with primary antibody; anti- $\beta$-catenin (Cell Signaling Technology). As a loading control, anti- $\beta$-actin antibody (Santa Cruz biotechnology) was used. Subsequently, the blots were washed in TBST (10 mM Tris- $\mathrm{HCl}, 50 \mathrm{mM} \mathrm{NaCl}, 0.25 \%$ Tween-20) and incubated with a horseradish peroxidase-conjugated secondary antibody. The presence of target proteins was detected using the enhanced chemiluminescence reagents (BioNote Inc., Hwaseong, Korea).

Lactate dehydrogenase $(\mathrm{LDH})$ activity assay. Measurement of LDH activity was performed with cytotoxicity detection kit (Roche) according to the manufacturer's protocol as follows. Cell culture media $(10 \mu \mathrm{l})$ from each experimental sample was added to a 96-well plate containing $40 \mu \mathrm{l}$ of PBS. Next, $50 \mu \mathrm{l}$ of $\mathrm{LDH}$ reagent was added to each well and plates were incubated for $45 \mathrm{~min}$ at $25^{\circ} \mathrm{C}$ in dark, and then enzymatic reaction was stopped by adding the stop solution $(50 \mu \mathrm{l})$. Absorbance was read at wavelength of $492 \mathrm{~nm}$. Total cell lysate served as a positive control of cell death.
Statistical analysis. All the statistical data were analyzed by GraphPad Prism 5.0 (GraphPad Software, San Diego, CA) and evaluated by two-tailed Student's t-test. Value of $\mathrm{P}<0.05$ was considered to indicate statistical significance.

\section{Results}

The treatment of quercetin delays the growth and induces apoptosis of $4 T 1$ cells. Initially, we attempted to determine whether quercetin could exert anti-proliferative effect on 4T1 mouse mammary cancer cell line as reported in case of diverse breast cancer cell lines (27-29). After treatment of quercetin at various doses for $48 \mathrm{~h}$, a dose-dependent decrease in cell viability of $4 \mathrm{~T} 1$ cells was observed (Fig. 1A). Cells taken as control showed increase in confluence from initial 60 to $100 \%$ after $48 \mathrm{~h}$ of culture. However, the cells treated with 10 and $20 \mu \mathrm{M}$ of quercetin reached only $70-80 \%$ of confluence. Moreover, a dose of $40 \mu \mathrm{M}$ of quercetin showed $50 \%$ decrease in initial cell number. Hence, for further experiments, $20 \mu \mathrm{M}$ of quercetin was selected as an ideal dose to detect the effect of quercetin. Since cell apoptosis may be one of the consequences of growth arrest, we stained the cells with Annexin V-FITC and $\mathrm{PI}$, and analyzed the apoptotic effect of quercetin on 4T1 cells using flow cytometry. Fig. 1B showed an increased apoptotic effect of quercetin at a dose of $20 \mu \mathrm{M}(37 \%)$ as compared to control (18\%). The population of early apoptotic cells increased $\sim 3$-fold compared to control whereas, significant increase in late apoptotic cells were also observed.

Wnt/ $\beta$-catenin signaling activity is decreased by quercetin. As $\mathrm{Wnt} / \beta$-catenin signaling pathway is implicated in regulating tumor growth (30), the effect of quercetin on Wnt/ $\beta$-catenin signaling pathway of 4T1 cells needed defining. To detect the activity of Wnt/ $\beta$-catenin signaling pathway, we used the luciferase reporter assay. 4T1 cells were transfected with TopFlash-luc for Wnt/ $\beta$-catenin signaling pathway. After $48 \mathrm{~h}$ of treatment, quercetin suppressed $\sim 50 \%$ of basal level of TopFlash luciferase activity, demonstrating inhibitory effect 


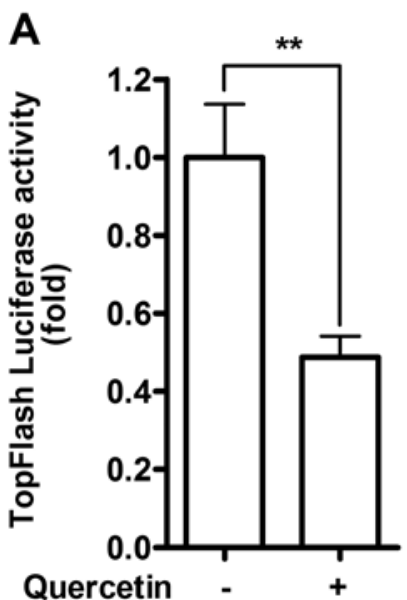

B

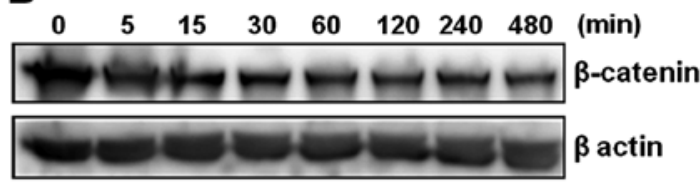

Figure 2. Effect of quercetin on Wnt/ $\beta$-catenin signaling pathway in 4T1 cells. (A) 4T1 cells were transiently transfected with TopFlash-luc reporter plasmids and treated with quercetin $(20 \mu \mathrm{M})$. After $48 \mathrm{~h}$, luciferase activity was measured in cell lysates and normalized to Renilla luciferase activity as described in Materials and methods. (B) After treatment of quercetin for 5, 15, $30,60,120,240$ and $480 \mathrm{~min}$, total cell lysates were collected and subjected to western blotting for analyzing stability of $\beta$-catenin protein. $\beta$-actin was measured as loading control. Data are shown as the mean \pm SD. Similar results were obtained in three independent experiments. ${ }^{* *} \mathrm{P}<0.01$.

of quercetin on Wnt/ $\beta$-catenin signaling pathway (Fig. 2A). Canonical Wnt signaling acts through stabilization of $\beta$-catenin, which translocate into the nucleus to regulate the expression of genes related to tumor growth, such as cyclin D1 and survivin (31). Thus, in order to confirm the inhibitory role of quercetin on Wnt/ $\beta$-catenin signaling pathway as observed by luciferase assay, the stability of $\beta$-catenin was detected by western blot analysis. We observed reduction of $\beta$-catenin stabilization in quercetin treated cells after $1 \mathrm{~h}$ of treatment, confirming inhibitory effect of quercetin on $\mathrm{Wnt} / \beta$-catenin signaling pathway (Fig. 2B).

Quercetin induces the gene expression of DKK1, 2, 3 and 4. $\mathrm{Wnt} / \beta$-catenin signaling pathway is regulated by several processes. Secreted proteins such as secreted frizzled-related protein (sFRP) and Dickkopf (DKK) act as extracellular antagonists and are among various mechanisms to regulate $\mathrm{Wnt} / \beta$-catenin signaling pathway $(32,33)$. To investigate whether various negative regulators of $\mathrm{Wnt} / \beta$-catenin signaling pathway is being upregulated in 4T1 cells by quercetin, we next examined the expression of known negative regulators by real-time RT-PCR. Among various antagonists screened for Wnt/ $\beta$-catenin signaling pathway, mRNA expression level of DKK1, 2, 3 and 4 was found to be elevated dose-dependently (Fig. 3), while any altered expression of sFRP family was not observed (data not shown). Expression of DKK1 increased more than 3-fold while increase in DKK2 and 3 was about 2-fold. A non-significant induction of DKK4 was observed when treated
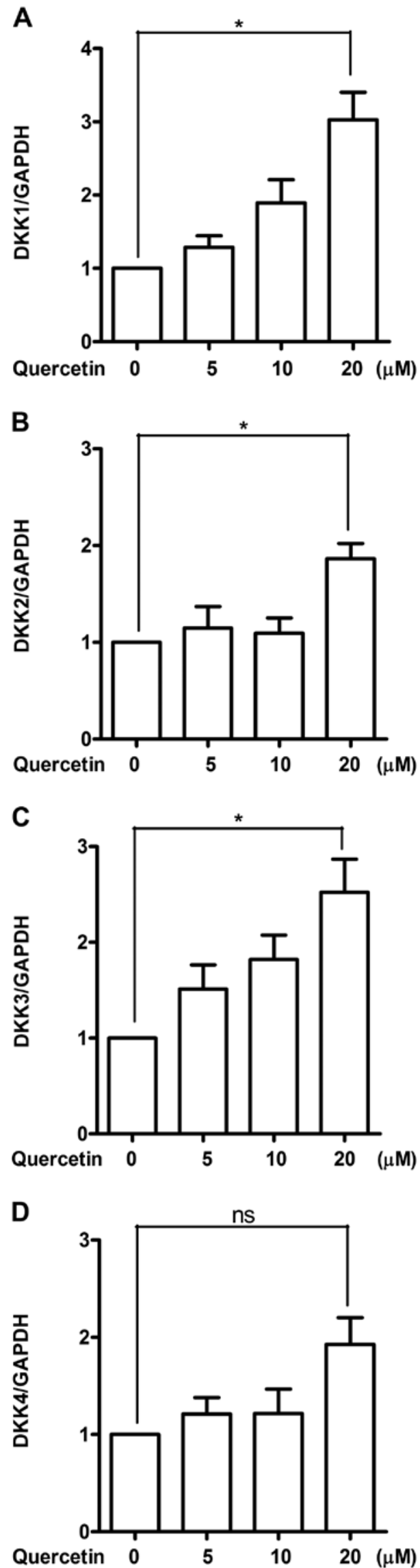

Figure 3. Quercetin upregulates expression of DKK. (A-D) After stimulation with quercetin $(5,10$ and $20 \mu \mathrm{M})$ for $48 \mathrm{~h}$, total cellular RNA was extracted and transcripts of DKK1, DKK2, DKK3 and DKK4 were analyzed by real-time RT-PCR. Data shown are normalized to GAPDH levels, and shown as the mean \pm SD. Similar results were obtained in three independent experiments. $* \mathrm{P}<0.05$. 


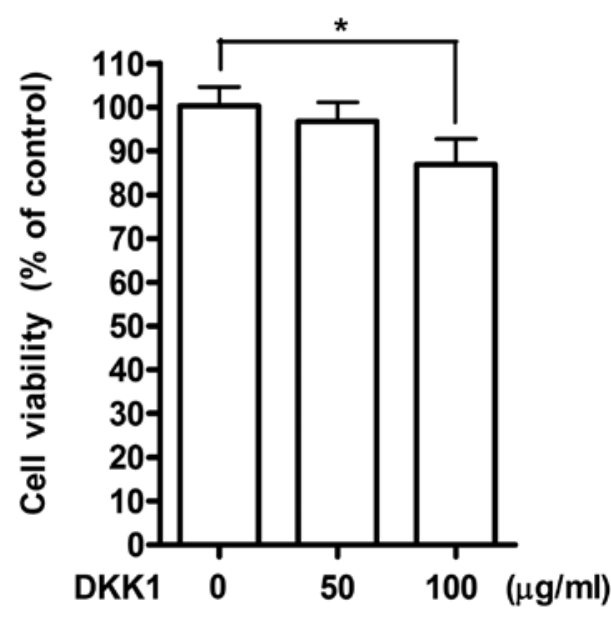

Figure 4. Effect of DKK1 on cell viability of 4T1 cells. 4T1 cells were treated with vehicle (PBS) and various doses of recombinant protein (DKK1; 50 and $100 \mathrm{ng} / \mathrm{ml}$ ) for $48 \mathrm{~h}$. Viability of cells was analyzed by MTT assay. Data are shown as the mean \pm SD. Similar results were obtained in three independent experiments. ${ }^{*} \mathrm{P}<0.05$.
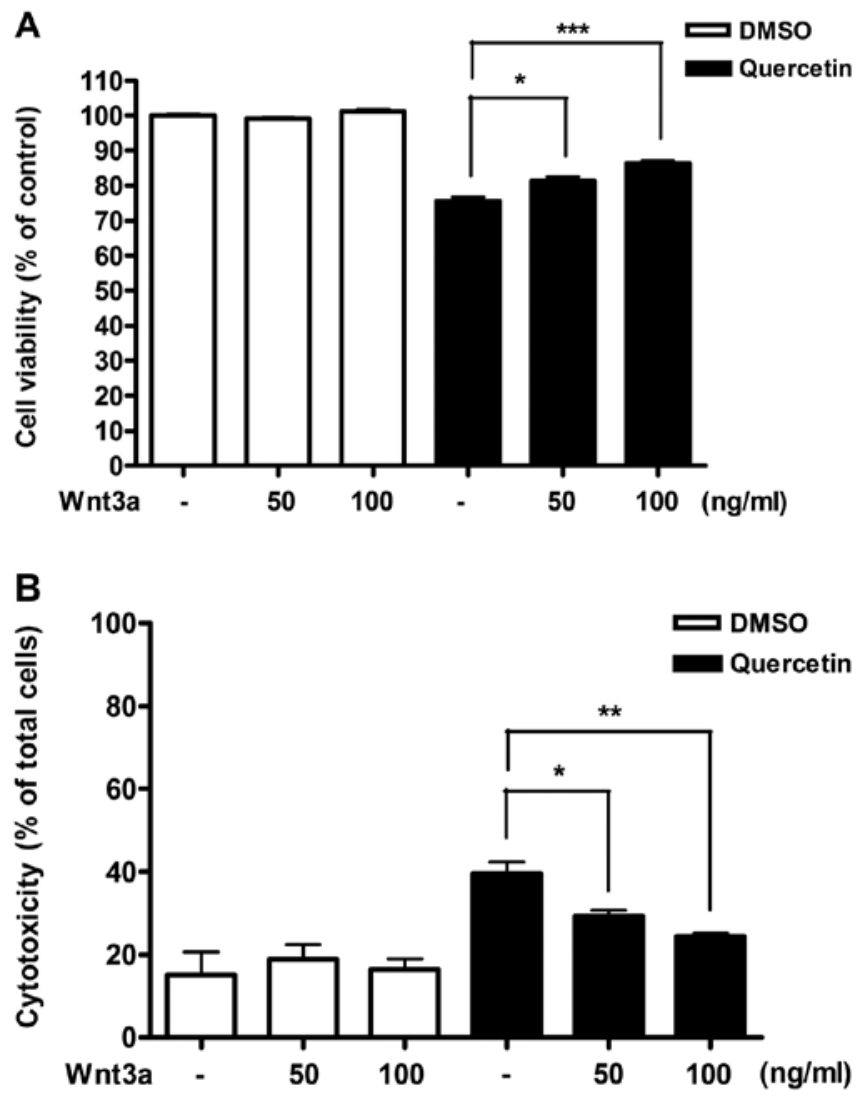

Figure 5. Effect of Wnt3a on cell viability and cytotoxicity of 4T1 cells treated with quercetin. Recombinant protein of Wnt3a was treated to 4T1 cells at various doses (50 and $100 \mathrm{ng} / \mathrm{ml})$ without or with quercetin $(20 \mu \mathrm{M})$. After $48 \mathrm{~h}$, cell viability and cytotoxicity was measured by (A) MTT and (B) LDH assay. Data are shown as the mean $\pm \mathrm{SD}$. Similar results were obtained in three independent experiments. ${ }^{*} \mathrm{P}<0.05,{ }^{* *} \mathrm{P}<0.01$ and ${ }^{* * *} \mathrm{P}<0.001$.

with $20 \mu \mathrm{M}$ of quercetin. Induced expressions of DKK family by quercetin suggest their involvement in regulating the $\mathrm{Wnt} / \beta$ catenin signaling pathway in our system as expected.
Exogenous treatment of DKK1 shows inhibitory effect on cell growth. Among DKK1, 2, 3 and 4, expression of DKK1 have been strongly implicated to proliferation ability of breast cancer cells via regulation of $\mathrm{Wnt} / \beta$-catenin signaling pathway $(34,35)$. Therefore, to confirm involvement of DKK1 as an antagonist for $\mathrm{Wnt} / \beta$-catenin signaling pathway after treatment with quercetin, $4 \mathrm{~T} 1$ cells were stimulated with recombinant DKK1 protein instead of quercetin. Stimulation with $100 \mu \mathrm{g} / \mathrm{ml}$ of recombinant DKK1 showed suppressive effect on cell growth as detected by MTT assay (Fig. 4). The inhibition on cell growth by DKK1 was partial $(\sim 10 \%)$ as compared to the effect of quercetin, suggesting the possibility of involvement of several other regulatory mechanisms by quercetin for the inhibition of cell growth along with DKK1.

Stimulation of Wnt/ $\beta$-catenin signaling pathway with Wnt3a or LiCl restored the effect of quercetin. From results obtained, we hypothesized that $\mathrm{Wnt} / \beta$-catenin signaling activity might be reduced by the induction of the secreted antagonists in response to quercetin. To investigate this possibility, we potentiated the activity of $\mathrm{Wnt} / \beta$-catenin signaling pathway by exogenous stimulation and observed whether activation of Wnt/ $\beta$-catenin pathway can effectively restore the inhibition of cell viability in 4T1 cells treated with quercetin. 4T1 cells were incubated with quercetin along with recombinant Wnt3a (Fig. 5), or LiCl (Fig. 6). After 48 h, cell viability was measured by MTT assay and cytotoxicity was detected by LDH assay. Both stimulators for Wnt/ $\beta$-catenin signaling pathway were able to restore the suppressed cell viability by quercetin in a dose-dependent manner, as well as inhibition of the increased cytotoxicity (Figs. 5 and 6). However, Wnt3a or LiCl did not show any individual effect on cell viability and cytotoxicity in absence of quercetin.

\section{Discussion}

The aim of the present study was to investigate the inhibitory role of quercetin on tumorigenic potential of murine mammary cancer cell line, 4T1, and to evaluate its ability for modulating Wnt/ $\beta$-catenin signaling pathway.

Quercetin is one of the major dietary flavonoids enriched in various fruits and vegetables. Recent studies report that quercetin exert a broad range of pharmacological effects and is a promising chemopreventive agent in a variety of cancer models $(36,37)$. Previous experimental studies indicate that quercetin possesses antitumor activity and induces apoptotic cell death of breast cancer cells by the activation of caspaseor p53-dependent pathway (38-40). Consistent with previous reports, our study showed that quercetin reduces viability and induces apoptosis even in murine mammary cancer cell line, 4T1 (Fig. 1). Though quercetin has attracted much attention in relation to its anticancer activities in many cancer cell models, the molecular mechanisms underlying quercetin-mediated cellular responses remain poorly defined.

The Wnt/ $\beta$-catenin signaling pathway has been demonstrated to play an important role in tumorigenesis (30). Initially, Wnt/ $\beta$ catenin signaling activation, as defined by $\beta$-catenin nuclear expression and overexpression of the cyclin D1, was reported to be associated with a poorer prognosis in breast cancer patients (27). Recent studies have confirmed the Wnt/ $\beta$-catenin signaling 

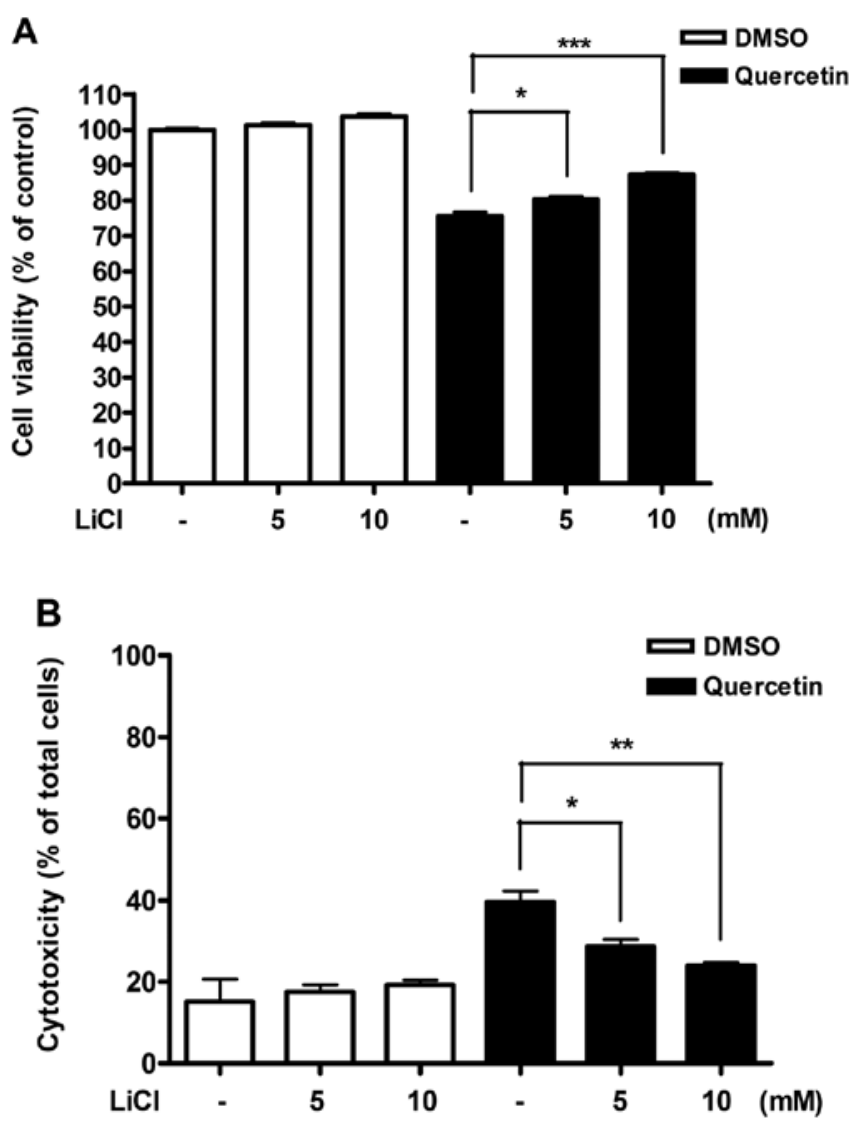

Figure 6. Effect of $\mathrm{LiCl}$ on cell viability and cytotoxicity of 4T1 cells treated with quercetin. $\mathrm{LiCl}$ treatment of $4 \mathrm{~T} 1$ cells at various doses $(5$ and $10 \mathrm{mM})$ without or with quercetin $(20 \mu \mathrm{M})$. After $48 \mathrm{~h}$, cell viability and cytotoxicity were measured by (A) MTT and (B) LDH assay. Data are shown as the mean \pm SD. Similar results were obtained in three independent experiments. ${ }^{*} \mathrm{P}<0.05,{ }^{* *} \mathrm{P}<0.01$ and ${ }^{* * *} \mathrm{P}<0.001$.

in both the pathogenesis of breast cancer and the regulation of normal mammary epithelial stem cell processes (41-43). A possible role for Wnt/\$-catenin signaling pathway in cancer was first described three decades ago in mouse models of mammary cancer and in human and mouse colon cancer. Moreover, different stages of mammary gland development have been shown to get controlled and regulated by Wnt/ $\beta$-catenin signaling (44). Despite the cancer preventive potential of quercetin and involvement of $\mathrm{Wnt} / \beta$-catenin signaling pathway in cancer progression, little is known about the modulation of Wnt/ $\beta$-catenin signaling by quercetin in breast cancer. According to our results of decreased TopFlash luciferase activity and $\beta$-catenin stability (Fig. 2), we suggest that regulation of Wnt/ $\beta$-catenin signaling may be one of the mechanisms responsible for suppression of cell viability in breast cancer by quercetin.

Next, we focused on to identify the regulatory mechanism that could answer the decreased Wnt/ $\beta$-catenin signaling activity in breast cancer cells after treatment of quercetin. Among various possible mechanisms, secretion of antagonists upstream of Wnt/ $\beta$-catenin signaling pathway could play a vital role in suppression of cell viability. Wnt/ $\beta$-catenin pathway is regulated by a variety of secreted proteins, such as WIF, DKK and sFRP that can competitively dislodge certain Wnt ligands from their receptors or contend for receptor binding. In a few cancer models, an increase in sFRP levels attenuates cancer growth, particularly in cells that require autocrine Wnt stimulation such as myeloma cells (45) and subsets of breast cancer cells (46). As expected, the expression level of DKK family was increased after stimulation with quercetin, and treatment with recombinant DKK1 showed suppressive effect on cell growth (Figs. 3 and 4). Previous studies have reported that the downregulation of DKK1 is due to the high proliferation ability of breast cancer cells via loss of control of $\beta$-catenin/TCF transcription cascade, and that DKK1 secreted by mesenchymal stem cells inhibits growth of breast cancer cells via depression of Wnt/ $\beta$-catenin signaling $(34,35)$. However, as the inhibitory effect of DKK1 on cell growth was much less than that of quercetin, the possibility of another mechanism remains to be studied. We cannot rule out the possible participation of other antagonists in regulation of $\mathrm{Wnt} / \beta$-catenin signaling activity. Also, the relative roles of DKK 2, 3 and 4 in the suppression of cell viability by quercetin remain to be elucidated. Besides, our data showed that exogenous stimulation of recombinant Wnt3a or $\mathrm{LiCl}$ for the activation of $\mathrm{Wnt} / \mathrm{\beta}$-catenin signaling pathway can effectively restore the inhibition of cell viability by quercetin (Figs. 5 and 6), indicating that the effect of quercetin in regulation of cell viability of cancer can be mediated by the modulation of $\mathrm{Wnt} / \beta$-catenin signaling pathway.

Collectively, our findings provide new insight into the mechanism of quercetin regulation of Wnt/ $\beta$-catenin signaling. Consequently, the inhibition of cell viability and induction of apoptosis in 4T1 mammary cancer cells with quercetin administration provide evidence for its potential for cancer treatment. Our results also highlight the importance of $\mathrm{Wnt} / \beta$-catenin signaling regulated by DKK family that may serve as a future target for therapeutic strategies to inhibit the development of breast cancer cells.

\section{Acknowledgements}

This research was supported by a grant from Basic Science Research Program through the National Research Foundation of Korea (NRF) funded by the Ministry of Education, Science and Technology (2012-0000312 and 2011-0015044), Korean Health Technology R\&D Project, Ministry of Health and Welfare, Republic of Korea (A121370), and Hallym University Medical Center Research Fund (01-2011-04).

\section{References}

1. DeSantis C, Siegel R, Bandi P and Jemal A: Breast cancer statistics, 2011. CA Cancer J Clin 61: 409-418, 2011.

2. Ren W, Qiao Z, Wang H, Zhu L and Zhang L: Flavonoids: promising anticancer agents. Med Res Rev 23: 519-534, 2003.

3. Baowen Q, Yulin Z, Xin W, et al: A further investigation concerning correlation between anti-fibrotic effect of liposomal quercetin and inflammatory cytokines in pulmonary fibrosis. Eur J Pharmacol 642: 134-139, 2010.

4. Boots AW, Haenen GR and Bast A: Health effects of quercetin: from antioxidant to nutraceutical. Eur J Pharmacol 585: 325-337, 2008.

5. Murakami A, Ashida $\mathrm{H}$ and Terao J: Multitargeted cancer prevention by quercetin. Cancer Lett 269: 315-325, 2008.

6. Wei YQ, Zhao X, Kariya Y, Fukata H, Teshigawara K and Uchida A: Induction of apoptosis by quercetin: involvement of heat shock protein. Cancer Res 54: 4952-4957, 1994.

7. Yoshida M, Sakai T, Hosokawa N, et al: The effect of quercetin on cell cycle progression and growth of human gastric cancer cells. FEBS Lett 260: 10-13, 1990. 
8. Choi EJ, Bae SM and Ahn WS: Antiproliferative effects of quercetin through cell cycle arrest and apoptosis in human breast cancer MDA-MB-453 cells. Arch Pharm Res 31: 1281-1285, 2008.

9. Gulati N, Laudet B, Zohrabian VM, Murali R and JhanwarUniyal M: The antiproliferative effect of quercetin in cancer cells is mediated via inhibition of the PI3K-Akt/PKB pathway. Anticancer Res 26: 1177-1181, 2006.

10. Lee YK and Park OJ: Regulation of mutual inhibitory activities between AMPK and Akt with quercetin in MCF-7 breast cancer cells. Oncol Rep 24: 1493-1497, 2010.

11. Eroles P, Bosch A, Perez-Fidalgo JA and Lluch A: Molecular biology in breast cancer: intrinsic subtypes and signaling pathways. Cancer Treat Rev 38: 698-707, 2012.

12. Grant S: Cotargeting survival signaling pathways in cancer J Clin Invest 118: 3003-3006, 2008

13. Cai J, Guan H, Fang L, et al: MicroRNA-374a activates Wnt/ $\beta$-catenin signaling to promote breast cancer metastasis. J Clin Invest 123: 566-579, 2013

14. Lu W, Lin C, King TD, Chen H, Reynolds RC and Li Y Silibinin inhibits Wnt/beta-catenin signaling by suppressing Wnt co-receptor LRP6 expression in human prostate and breast cancer cells. Cell Signal 24: 2291-2296, 2012.

15. Wu Y, Ginther C, Kim J, et al: Expression of Wnt3 activates Wnt/beta-catenin pathway and promotes EMT-like phenotype in trastuzumab-resistant HER2-overexpressing breast cancer cells. Mol Cancer Res 10: 1597-1606, 2012.

16. Tsukamoto AS, Grosschedl R, Guzman RC, Parslow T and Varmus HE: Expression of the int-1 gene in transgenic mice is associated with mammary gland hyperplasia and adenocarcinomas in male and female mice. Cell 55: 619-625, 1988.

17. Clevers $\mathrm{H}$ : Wnt/beta-catenin signaling in development and disease. Cell 127: 469-480, 2006.

18. Ryo A, Nakamura M, Wulf G, Liou YC and Lu KP: Pin1 regulates turnover and subcellular localization of beta-catenin by inhibiting its interaction with APC. Nat Cell Biol 3: 793-801, 2001.

19. Huang M, Wang Y, Sun D, et al: Identification of genes regulated by Wnt/beta-catenin pathway and involved in apoptosis via microarray analysis. BMC Cancer 6: 221, 2006.

20. Li Y, Welm B, Podsypanina K, et al: Evidence that transgenes encoding components of the Wnt signaling pathway preferentially induce mammary cancers from progenitor cells. Proc Natl Acad Sci USA 100: 15853-15858, 2003.

21. Teissedre B, Pinderhughes A, Incassati A, Hatsell SJ, Hiremath $\mathrm{M}$ and Cowin P: MMTV-Wnt1 and -DeltaN89betacatenin induce canonical signaling in distinct progenitors and differentially activate Hedgehog signaling within mammary tumors. PLoS One 4: e4537, 2009.

22. Khramtsov AI, Khramtsova GF, Tretiakova M, Huo D, Olopade OI and Goss KH: Wnt/beta-catenin pathway activation is enriched in basal-like breast cancers and predicts poor outcome. Am J Pathol 176: 2911-2920, 2010.

23. Lin SY, Xia W, Wang JC, et al: Beta-catenin, a novel prognostic marker for breast cancer: its roles in cyclin D1 expression and cancer progression. Proc Natl Acad Sci USA 97: 4262-4266, 2000.

24. Aslakson CJ and Miller FR: Selective events in the metastatic process defined by analysis of the sequential dissemination of subpopulations of a mouse mammary tumor. Cancer Res 52: 1399-1405, 1992.

25. Yoneda T, Michigami T, Yi B, Williams PJ, Niewolna M and Hiraga T: Actions of bisphosphonate on bone metastasis in animal models of breast carcinoma. Cancer 88: 2979-2988, 2000.

26. Choi JA, Kim JY, Lee JY, et al: Induction of cell cycle arrest and apoptosis in human breast cancer cells by quercetin. Int $\mathrm{J}$ Oncol 19: 837-844, 2001
27. Avila MA, Velasco JA, Cansado J and Notario V: Quercetin mediates the down-regulation of mutant p53 in the human breast cancer cell line MDA-MB468. Cancer Res 54: 2424-2428, 1994.

28. Rodgers EH and Grant MH: The effect of the flavonoids, quercetin, myricetin and epicatechin on the growth and enzyme activities of MCF7 human breast cancer cells. Chem Biol Interact 116: 213-228, 1998.

29. Brusselmans K, Vrolix R, Verhoeven G and Swinnen JV: Induction of cancer cell apoptosis by flavonoids is associated with their ability to inhibit fatty acid synthase activity. J Biol Chem 280: 5636-5645, 2005 .

30. Brennan KR and Brown AM: Wnt proteins in mammary development and cancer. J Mammary Gland Biol Neoplasia 9: 119-131, 2004

31. Giles RH, van Es JH and Clevers H: Caught up in a Wnt storm: Wnt signaling in cancer. Biochim Biophys Acta 1653: 1-24, 2003.

32. Suzuki H, Toyota M, Carraway H, et al: Frequent epigenetic inactivation of Wnt antagonist genes in breast cancer. Br J Cancer 98: 1147-1156, 2008

33. Bafico A, Liu G, Goldin L, Harris V and Aaronson SA: An autocrine mechanism for constitutive Wnt pathway activation in human cancer cells. Cancer Cell 6: 497-506, 2004.

34. Zhou XL, Qin XR, Zhang XD and Ye LH: Downregulation of Dickkopf-1 is responsible for high proliferation of breast cancer cells via losing control of Wnt/beta-catenin signaling. Acta Pharmacol Sin 31: 202-210, 2010.

35. Qiao L, Xu ZL, Zhao TJ, Ye LH and Zhang XD: Dkk-1 secreted by mesenchymal stem cells inhibits growth of breast cancer cells via depression of Wnt signalling. Cancer Lett 269: 67-77, 2008.

36. Jeong JH, An JY, Kwon YT, Rhee JG and Lee YJ: Effects of low dose quercetin: cancer cell-specific inhibition of cell cycle progression. J Cell Biochem 106: 73-82, 2009.

37. Gibellini L, Pinti M, Nasi M, et al: Quercetin and cancer chemoprevention. Evid Based Complement Alternat Med 2011: 591356, 2011.

38. Seo HS, Ju JH, Jang K and Shin I: Induction of apoptotic cell death by phytoestrogens by up-regulating the levels of phosphop53 and p21 in normal and malignant estrogen receptor alpha-negative breast cells. Nutr Res 31: 139-146, 2011.

39. Chou CC, Yang JS, Lu HF, et al: Quercetin-mediated cell cycle arrest and apoptosis involving activation of a caspase cascade through the mitochondrial pathway in human breast cancer MCF-7 cells. Arch Pharm Res 33: 1181-1191, 2010.

40. Chien SY, Wu YC, Chung JG, et al: Quercetin-induced apoptosis acts through mitochondrial- and caspase-3-dependent pathways in human breast cancer MDA-MB-231 cells. Hum Exp Toxicol 28: 493-503, 2009.

41. Nusse R: Wnt signaling in disease and in development. Cell Res 15: 28-32, 2005.

42. Lindvall $\mathrm{C}, \mathrm{Bu} \mathrm{W}$, Williams $\mathrm{BO}$ and $\mathrm{Li} \mathrm{Y}$ : Wnt signaling, stem cells, and the cellular origin of breast cancer. Stem Cell Rev 3: $157-168,2007$.

43. Anastas JN and Moon RT: WNT signalling pathways as therapeutic targets in cancer. Nat Rev Cancer 13: 11-26, 2013.

44. Prosperi JR and Goss KH: A Wnt-ow of opportunity: targeting the Wnt/beta-catenin pathway in breast cancer. Curr Drug Targets 11: 1074-1088, 2010.

45. Chim CS, Pang R, Fung TK, Choi CL and Liang R: Epigenetic dysregulation of Wnt signaling pathway in multiple myeloma. Leukemia 21: 2527-2536, 2007.

46. Matsuda Y, Schlange T, Oakeley EJ, Boulay A and Hynes NE: WNT signaling enhances breast cancer cell motility and blockade of the WNT pathway by sFRP1 suppresses MDA-MB-231 xenograft growth. Breast Cancer Res 11: R32, 2009. 